Jurnal Pendidikan Sosial Keberagaman

Print-ISSN 2355-4622 Online-ISSN 2622-9021

Vol. 6, No. 1, Oktober-Maret 2019, hh. 57-66

https://juridiksiam.unram.ac.id/index.php/juridiksiam

\title{
IMPLEMENTASI PEMBELAJARAN BERDASARKAN GENDER \\ (Studi di Sekolah Menengah Pertama Negeri 1 Kediri Kecamatan Kediri Kabupaten Lombok Barat)
}

\author{
Ridho Aditya ${ }^{1}$, Muh. Mabrur Haslan ${ }^{2}$, Yuliatin ${ }^{3}$ \\ ${ }^{1}$ Mahasiswa prodi PPKn, ${ }^{23}$ Dosen Jurusan Pendidikan IPS \\ Fakultas Keguruan dan Ilmu Pendidikan Universitas Mataram \\ Email: Mabrurhaslan29gmail.com
}

\begin{abstract}
ABSTRAK
Penelitian ini bertujuan untuk mendeskripsikan: (1) latar belakang implementasi pembelajaran berdasarkan gender di SMP Negeri 1 Kediri (2) implementasi pembelajaran berdasarkan gender di SMP Negeri 1 Kediri (3) kelebihan dan kekurangan implementasi pembelajaran berdasarkan gender di SMP Negeri 1 Kediri. Temuan dalam penelitian yaitu: 1) latar belakang implementasi pembelajaran berdasarkan gender adalah: a) berada di wilayah religius; b) laporan dari orang tua siswa; c) kepala sekolah mendapat ilmu kebijakan pemisahan kelas; d) mengurangi kontak fisik siswa. 2) implementasi pembelajaran berdasarkan gender: a) Pada perencanaan, tidak ada perbedaan untuk kelas lakilaki dan perempuan; b) Pada pelaksanaan, terdapat perbedaan yang cukup signifikan antara kelas lakilaki dan perempuan; c) Pada penilaian, terdapat beberapa perbedaan kriteria penilaian pada siswa lakilaki dan perempuan 3) kelebihan: a) Bagi siswa: lebih konsentrasi, berani mengungkapkan pendapat, leluasa bergaul di kelas, hubungan yang erat antarsiswa, meningkatkan motivasi belajar; b) bagi guru: nyaman mengajar, mudah mengurus kelas, mudah membagi kelompok diskusi, pembelajaran berhasil, memiliki kompetensi kepribadian; c) bagi sekolah: memiliki keunikan, berbaur dengan pendidikan agama sekitar; (c) daya tarik bagi wali murid; (d) jumlah peserta didik meningkat. 3) kekurangan: a) bagi siswa: motivasi belajar berkurang, daya saing berkurang, kelas lakilaki menjadi ribut; perempuan bertingkah semena-mena, tidak terlalu memperhatikan kebersihan kelas; b) bagi guru: belum bisa mengatur kelas laki-laki; harus terlihat galak; Bagi sekolah: belum mampu menambah sarana dan prasarana.
\end{abstract}

\section{Kata kunci: implementasi pembelajaran, gender}

\section{ABSTRACT}

This study aims to describe: (1) the background of the implementation of genderbased learning in Kediri Middle School 1 (2) the implementation of genderbased learning in Junir High School 1 Kediri (3) the advantages and disadvantages of implementing genderbased learning in Junir High School 1 Kediri. Findings in the study are: 1) the background to the implementation of genderbased learning are: a) being in a religious area; b) reports from parents of students; c) the principal gets the knowledge of class separation policy; d) reduce student physical contact. 2) implementation of genderbased learning: a) In planning, there is no difference for male and female classes; b) In implementation there are significant differences between male and female classes; c) In the assessment, there are several differences in assessment criteria for male and female students 3) strengths: a) For students: more concentration, daring to express opinions, freæo hang out in class, close relationships between students, increase learning motivation; b) for teachers: comfortable teaching, easy to take care of classes, easy to share discussion groups, successful learning, have personality competencies; c) for schools: uniqueness, mingling with religious education around; (c) attraction for student guardians; (d) the number of students increases. 3) deficiencies: a) for students: learning motivation decreases, competitiveness decreases, male class becomes noisy; women behave arbitrarily, not paying too 
much attention to class cleanliness; b) for teachers: not able to regulate male classes; must look fierce; For schools: have not been able to add facilities and infrastructure.

\section{Keywords: implementation of learning, gender}

\section{PENDAHULUAN}

Pembelajaran berdasarkan Undang-Undang Republik Indonesia No 20 Tahun 2003 tentang Sistem Pendidikan Nasional Pasal 1 Bab I, adalah proses interaksi peserta didik dengan pendidik dan sumber belajar pada suatu lingkungan belajar. Dengan demikian interaksi siswa dengan guru atau sumber belajar yang lain dalam lingkungan belajar dapat disebut pembelajaran.

Dalam pembelajaran di sekolah, siswa sebagai peserta didik merupakan pribadi-pribadi yang unik dengan segala karakteristiknya. Dalam hal ini guru dituntut untuk berlaku secara merata atau adil entah bagaimana beragamnya karakter-karakter yang dimiliki oleh siswa, baik itu laki-laki maupun perempuan agar tidak terjadi ketimpangan selama proses pembelajaran berlangsung (Mursidah, 2013: 4).

Sehubungan dengan hal tersebut, maka pembelajaran yang dilakukan oleh guru dalam proses pembelajaran di sekolah harus sesuai dengan kondisi dan kebutuhan siswa, karena siswa laki-laki dan perempuan memiliki karakteristik dan kebutuhan yang berbeda. Selain itu, pembelajaran yang sesuai dengan kebutuhan dan karakteristik siswa sangat bermanfaat bagi siswa laki-laki maupun perempuan, terutama untuk mewujudkan keadilan dan kesetaraan gender diantara keduanya sehingga dapat mencapai pertumbuhan, perkembangan, dan kedamaian dalam kehidupan di lingkungan sekolah.

Namun pada saat ini stereotip gender dalam kehidupan sehari-hari masih tetap dominan. Stereotip itu misalnya perempuan dibentuk untuk lemah lembut, maka apabila menangis pasti disayang dan digendong dengan lembut, patuh dan tidak banyak tingkah, sementara laki-laki dibentuk untuk menjadi kuat dan tegar apabila anak laki-laki yang menangis maka dibiarkan saja dan hanya disuruh untuk diam karena laki-laki tidak boleh menangis serta menjadi dalang adanya kekacauan (Taqiyah, 2006:3).

Hal di atas pun berlaku juga di dalam lingkungan sekolah. Stereotip guru mengenai karakter siswa yang berbeda ini memicu adanya ketimpangan yang dilakukan oleh guru. Sebagian besar guru memiliki pemahaman bahwa siswa perempuan akan memudahkan mereka selama proses belajar mengajar di sekolah karena mereka tidak akan berbuat hal-hal yang menyimpang. Siswa perempuan selalu dianggap patuh, sopan, rajin, dan disiplin sehingga guru akan lebih memperioritaskan dan bersikap baik, sedangkan tidak demikian jika dibandingkan dengan siswa laki-laki.

Sekolah yang paling berpotensi untuk menyajikan fenomena seperti di atas adalah sekolah yang memisahkan rombongan belajar siswa berdasarkan jenis kelamin sehingga dalam hal ini dapat kita temui bahwa siswa laki-laki akan bergabung dengan sesama laki-laki, kemudian siswa perempuan akan bergabung dengan sesama perempuan. Salah satu sekolah yang menerapkan pemisahan kelas berdasarkan jenis kelamin ini adalah SMPN 1 Kediri Lombok Barat. 
SMPN 1 Kediri merupakan sekolah negeri yang menerapkan pemisahan kelas antara siswa laki-laki dan perempuan selama hampir 4 tahun terakhir. Hal ini dikarenakan lokasi sekolah yang berada di dalam ruang lingkup kota santri dan dikelilingi oleh berbagai pondok pesantren yang menerapkan pemisahan sekolah antara laki-laki dan perempuan. Tujuan dari pemisahan kelas siswa laki-laki dan perempuan agar siswa fokus selama proses pembelajaran berlangsung dan menjaga pergaulan antara laki-laki dan perempuan (Wawancara: 27 November 2017).

Dari hasil studi pendahuluan yang peneliti laksanakan, fenomena pembelajaran di dalam kelas berlangsung cukup kondusif, baik itu di kelas laki-laki maupun perempuan. Suasana pembelajaran dapat terlihat lebih aktif karena siswa merasa lebih aman, tidak malu karena tidak ada lawan jenis, menekan nafsu terhadap lawan jenis, lebih konsentrasi, dapat menjaga diri dan keimanan lebih tinggi, menekan adanya pelecehan seksual, serta prestasi belajar meningkat (Wawancara: 23 Mei 2018).

Berdasarkan uraian latar belakang diatas, maka dapat dirumuskan permasalahan dalam peneltian ini adalah: (1) Apa latar belakang implementasi pembelajaran berdasarkan gender di SMP Negeri 1 Kediri? (2) Bagaimana implementasi pembelajaran berdasarkan gender di SMP Negeri 1 Kediri? (3) Apa kelebihan dan kekurangan implementasi pembelajaran berdasarkan gender di SMP Negeri 1 Kediri? Kemudian dari rumusan masalah tersebut maka dapat diketahui tujuan dari penelitian ini adalah: (1) Untuk mengetahui latar belakang implementasi pembelajaran berdasarkan gender di SMP Negeri 1 Kediri; (2) Untuk mengetahui implementasi pembelajaran berdasarkan gender di SMP Negeri 1 Kediri; dan (3) Untuk mengetahui kelebihan dan kekurangan implementasi pembelajaran berdasarkan gender di SMP Negeri 1 Kediri.

\section{METODE PENELITIAN}

Penelitian ini menggunakan penedekatan kualitatif dengan metode deskriptif, karena penelitian ini akan mendeskripsikan atau menggambarkan secara mendalam tentang latar belakang pemisahan kelas di SMPN 1 Kediri, implementasi pembelajaran berdasarkan gender di SMPN 1 Kediri dan kelebihan serta kekurangan implementasi pembelajaran berdasarkan geder.Tempat penelitian ini dilakukan di SMPN 1 Kediri, Kecamatan Kediri, Kabupaten Lombok Barat. Penelitian ini telah dilaksanakan mulai bulan Oktober 2018 .

Subyek dalam penelitian ini adalah guru-guru SMPN 1 Kediri. Subyek peneltian ditentukan dengan menggunakan purposive sampling, dengan pertimbangan-pertimbangan: guru yang telah mengajar 5 tahun, PNS, guru yang mengajar di kelas laki-laki dan perempuan di angkatan yang sama, dan sesuai dengan rekomendasi kepala sekolah. Informan dalam penelitian ini adalah Kepala Sekolah dan wakil kepala sekolah bagian Kurikulum. 


\section{HASIL PENELITIAN}

\section{Latar belakang implementasi pembelajaran berdasarkan gender di SMP Negeri 1 Kediri}

a. Sejarah

Terkait dengan latar belakang tersebut, berikut data hasil wawancara yang peneliti lakukan bersama dengan informan M, bahwa: "sejarah yang pertama itu karena SMP Negeri 1 Kediri ini dikelilingi oleh pondok pesantren. Di depan ada pondok pesantren Nurul Hakim, disebelah timur ada pondok pesantren Al-Ishlahuddiny, di sebelah barat ada pondok pesantren Al-Amin, di sebelah selatan ada pondok pesantren Selaparang, di sebelah utara ada pondok pesantren Yusuf Abdussatar. Kedua, karena banyaknya laporan yang masuk ke BP, orang tua dari siswa-siswa perempuan banyak yang melapor bahwa anaknya diganggu oleh siswa laki-laki. Kemudian saya memiliki ide atau kebijakan untuk memisahkan kelas antara siswa laki-laki dan perempuan agar mengurangi kejadian-kejadian yang tidak diinginkan antara siswa laki-laki dan perempuan" (wawancara, 29 September 2018)

b. Filosofi

Terkait dengan latar belakang tersebut, berikut data hasil wawancara yang peneliti lakukan bersama dengan informan $\mathrm{M}$, bahwa: "dengan pembelajaran berdasarkan gender ini siswa menjadi lebih konsentrasi dalam belajar, karena tidak ada lawan jenis yang menarik perhatiannya. Tentu saja pembelajaran berdasarkan gender ini dilakukan karena pertimbangan dari segi agama khususnya agama Islam, karena dalam agama Islam memberikan batasan-batasan dalam pergaulan antara laki-laki dan perempuan. Yaitu mengurangi kontak fisik antara siswa laki-laki dan perempuan karena mereka bukan muhrim dan mengurangi zina mata bagi kaum laki-laki" (wawancara, 29 September 2018).

\section{Implementasi pembelajaran berdasarkan gender di SMP Negeri 1 Kediri}

1. Rancangan Pelaksanaan Pembelajaran (RPP)

Hasil penelitian menunjukkan bahwa RPP yang digunakan untuk kelas laki-laki dan perempuan adalah sama. Hal ini sesuai dengan subjek 002 mengungkapkan bahwa: “Tidak ada perbedaan antara komponen RPP yang saya gunakan di kelas laki-laki dan perempuan, tapi mungkin pembawaan cara mengajar yang disesuaikan dengan kondisi kelas"(wawancara, 29 September 2018). Hal serupa juga dikemukakan oleh subjek 003 bahwa: "Kalau RPP sih sama, tidak ada perbedaan. Saya buat satu RPP untuk semua kelas laki-laki maupun perempuan. Tapi nanti disesuaikan lagi sama kondisi kelasnya"(wawancara, 29 September 2018)

2. Kegiatan Awal Pembelajaran

Dalam menerapkan kegiatan awal pembelajaran, subjek 001-003 menuturkan bahwa: “...tidak ada perbedaan antara kegiatan awal di kelas laki-laki dan perempuan. Yang saya lakukan adalah melakukan pembukaan dengan salam, mempersilahkan siswa untuk berdoa, memeriksa kehadiran siswa, mengaitkan 
materi yang akan disampaikan dengan kehidupan nyata, memberikan gambaran tentang manfaat mempelajari materi yang akan disampaikan, menyampaikan tujuan pembelajaran pada pertemuan yang berlangsung" (wawancara, 29 September 2018).

3. Kegiatan inti pembelajaran

Dalam kegiatan inti, subjek 001 menurutkan bahwa:"tidak ada perbedaan antara kegiatan inti di kelas laki-laki dan perempuan"(wawancara, 29 September 2018). Berbeda halnya dengan subjek 002 yang mengungkapkan bahwa: "Sama aja, tapi mungkin ada beberapa yang berbeda seperti penerapan metode pembelajaran. Untuk kelas laki-laki, saya lebih banyak ceramahnya biar mereka semua mendengar. Kalau perempuan juga ceramah tapi durasinya lebih sedikit dan langsung memberikan tugas" (wawancara, 29 September 2018)

4. Kegiatan penutup pembelajaran

Dalam kegiatan penutup pembelajaran, subjek penelitian mengungkapkan menjawab hampir sama. Dimana subjek 001 menatakan bahwa: "tidak ada perbedaan, seperti biasa memberi kesimpulan dan doa" (wawancara, 29 September 2018). Selanjutnya, subjek 002 mengungkapkan bahwa: "tidak ada, kalau penutup tidak ada perbedaan" (wawancara, 29 September 2018).

\section{Kelebihan dan kekurangan implementasi pembelajaran berdasarkan gender di SMP Negeri 1 Kediri}

1. Kelebihan

Kelebihan bagi siswa diungkapkan oleh informan 001, bahwa: "siswa menjadi lebih konsentrasi saat belajar, siswa menjadi lebih leluasa dalam bergaul di kelas karena tidak ada lawan jenisnya, pada saat proses pembelajaran berlangsung, siswa tidak malu untuk mengungkapkan pendapatnya karena tidak ada lawan jenisnya" (wawancara, 29 September 2018). Selanjutnya subjek 001 mengatakan bahwa: "siswa menjadi lebih leluasa dalam bergaul di kelas, tidak dibatasi oleh lawan jenisnya pada saat berdiskusi ataupun bersentuhan"

2. Kekurangan

Kekurangan bagi siswa diungkapkan oleh subjek 001 “....sekolah belum bisa menambah sarana dan prasarana untuk mendukung pemisahan kelas antara siswa laki-laki dan perempuan ini. Rencananya akan dibangun kantin, wc dan tempat bermain khusus untuk siswa laki laki dan perempuan..." (wawancara, 29 September 2018). Hal serupa juga diungkapkan oleh subjek 001, bahwa: "sekolah belum bisa memfasilitasi agar toilet dan kantin siswa juga dipisah, hal ini tentu saja berkaitan dengan anggaran" (wawancara, 29 September 2018). 


\section{PEMBAHASAN}

\section{Latar Belakang Implementasi Pembelajaran Berdasarkan Gender di SMP Negeri 1 Kediri}

Berdasarkan deskripsi data hasil penelitian, dapat dicermati bahwa latar belakang implementasi pembelajaran berdasarkan gender adalah sebagai berikut:

1. Karena SMP Negeri 1 Kediri merupakan sekolah yang berada di wilayah Kediri, dimana daerah tersebut merupakan daerah religius dan dikelilingi oleh pondok pesantren. Secara strategis, SMP Negeri 1 Kediri berhadapan dengan pondok pesantren Nurul Hakim, disebelah timur pondok pesantren Al-Ishlahuddiny, di sebelah barat pondok pesantren Al-Amin, di sebelah selatan pondok pesantren Selaparang dan di sebelah utara pondok pesantren Yusuf Abdussatar.

2. Karena banyaknya laporan yang masuk ke guru BK (Bimbingan Konseling), orang tua dari siswa-siswa perempuan banyak yang melapor bahwa anaknya diganggu oleh siswa laki-laki. Hal ini sesuai dengan pendapat Megasari (2015: 2) bahwa pengelompokkan kelas laki-laki dan perempuan dilakukan untuk mencegah terjadinya fitnah dan pergaulan bebas yang tidak diharapkan.

\section{Implementasi Pembelajaran Berdasarkan Gender di SMP Negeri 1 Kediri}

1. Perencanaan pembelajaran

a. Rencana Pelaksanaan Pembelajaran (RPP)

Dalam implementasi pembelajaran berdasarkan gender di SMP Negeri 1 Kediri, hasil penelitian menunjukkan bahwa Rencana Pelaksaan Pembelajaran yang dibuat dan digunakan oleh guru adalah sama, baik untuk kelas laki-laki dan perempuan. Hal ini berbeda dengan pendapat oleh Nanang Hanafiah dan Cucu Suhana (2012: 122) bahwa dalam menyusun RPP harus menerapkan prinsip memperhatikan perbedaan individu peserta didik. RPP disusun dengan memperhatikan perbedaan jenis kelamin, kemampuan awal, tingkat intelektual, minat, motivasi belajar, bakat, potensi, kemampuan sosial, emosi, gaya belajar, latar belakang budaya, norma, nilai, dan atau lingkungan peserta didik.

b. Buku ajar

Dalam penggunaan buku ajar, guru di SMP Negeri 1 Kediri menggunakan buku ajar yang diterbitkan oleh pemerintah dan diedarkan untuk setiap guru sebagai pegangan mengajar di kelas. Guru-guru di SMP Negeri 1 Kediri ini menggunakan buku ajar yang sama untuk kelas laki-laki maupun perempuan.

2. Pelaksanaan pembelajaran

a. Kegiatan pendahuluan 
Dari kegiatan pendahuluan yang dilaksanakan oleh guru, dapat ditunjukkan bahwa guru melakukan apersepsi seperti memberikan motivasi, menanyakan kehadiran, berdo'a, menguji kemampuan awal siswa, dan menyampaikan garis besar materi yang akan disampaikan baik di kelas laki-laki maupun perempuan. Menurut Syaiful Bahri dan Aswan Zain (2010 : 1) kegiatan pendahuluan adalah kegiatan yang dilakukan oleh guru untuk menciptakan suasana pembelajaran yang memungkinkan siswa siap secara mental untuk mengikuti kegiatan pembelajaran.

b. Kegiatan inti

Dari hasil penelitian yang peneliti lakukan, metode pembelajaran yang diterapkan di kelas perempuan cenderung bervariatif. Hal ini dikarenakan siswa perempuan sangat interaktif, antusias, dan bertanggungjawab dalam menyelesaikan tugas-tugas yang diberikan oleh guru. Sehingga, guru dengan mudah akan memilih metode pembelajaran karena kemampuan siswa perempuan yang cukup baik.

c. Kegiatan Penutup

Dalam kegiatan ini guru melakukan evaluasi terhadap materi yang telah disampaikan. Tujuan kegiatan menutup pelajaran adalah: 1) mengetahui tingkat keberhasilan siswa dalam mempelajari materi pembelajaran; 2) mengetahui tingkat keberhasilan guru dalam melaksanakan kegiatan pembelajaran; 3) membuat rantai kompetensi antara materi sekarang dengan materi yang akan datang.

3. Penilaian

a. Penilaian sikap

Adapun sikap yang dinilai di sekolah tersebut adalah sikap spiritual dan sikap sosial. Dalam kelas laki-laki maupun perempuan, terdapat beberapa kriteria penilaian yakni dalam sikap spiritual adalah selalu bersyukur dan berdoa sebelum melakukan kegiatan serta toleransi yang baik pada agama yang berbeda dan ketaatan beribadah mulai berkembang.

b. Penilaian pengetahuan

Penilaian pengetahuan terbagi menjadi tiga, yakni tes tulis, tes lisan, dan penugasan. Dalam menilai pengetahuan siswa, tidak ada perbedaan dari ketiga aspek tersebut baik laki-laki maupun perempuan.

c. Penilaian keterampilan

Dalam penilaian keterampilan ini, terdapat beberapa perbedaan tugas yang diberikan kepada siswa laki-laki dan perempuan. Siswa perempuan mendapatkan proyek, produk, dan praktik yang berkesinambungan. Namun untuk siswa laki-laki, guru hanya memberikan tugas portofolio diakhir 
pembelajaran dan nanti pada akhir semester, portofolio tersebut dikumpulkan sebagai nilai keterampilan siswa.

\section{Kelebihan dan Kekurangan Implementasi Pembelajaran Berdasarkan Gender di SMP Negeri 1 Kediri}

1. Kelebihan
a) siswa menjadi lebih konsentrasi saat belajar
b) pada saat proses pembelajaran berlangsung, siswa tidak malu untuk mengungkapkan pendapatnya;
c) siswa menjadi lebih leluasa dalam bergaul di kelas, tidak dibatasi oleh lawan jenisnya pada saat berdiskusi ataupun bersentuhan;
d) adanya hubungan yang erat antar siswa karena memiliki kesamaan secara biologis dan terjalin hubungan timbal balik yang intens;
e) meningkatkan motivasi belajar siswa, karena keadaan kelas tersebut mengalami interaksi yang baik.

2. Kekurangan
a) kekurangan dari pemisahan kelas ini terlihat pada kelas laki-laki, karena mereka digabung sesama laki-laki menyebabkan mereka menjadi tidak malu untuk berbuat nakal atau ribut di kelas karena tidak ada lawan jenisnya;
b) Selanjutnya di kelas perempuan, mereka cenderung bertingkah semena-mena seperti berteriak, bergosip, berlari, tidur karena tidak ada lawan jenisnya;
c) Siswa laki-laki tidak terlalu memperhatikan kebersihan kelasnya sehingga banyak sampah yang berserakan di dalam kelas.

\section{PENUTUP}

\section{Simpulan}

1. Latar Belakang Implementasi Pembelajaran Berdasarkan Gender di SMP Negeri 1 Kediri adalah: a) karena SMP Negeri 1 Kediri merupakan sekolah yang berada di wilayah religius; b) karena banyaknya laporan dari orang tua siswa perempuan; c) kepala sekolah mendapat ilmu kebijakan pemisahan kelas di New Zealand; d) untuk mengurangi kontak fisik antara siswa laki-laki dan perempuan.

2. Implementasi Pembelajaran Berdasarkan Gender di SMP Negeri 1 Kediri, antara lain: 1) Pada perencanaan pembelajaran, tidak ada perbedaan baik dari RPP maupun buku ajar yang disusun guru untuk kelas laki-laki dan perempuan; 2) Pada pelaksanaan pembelajaran, terdapat perbedaan yang cukup signifikan antara kelas laki-laki dan perempuan, baik dari metode yang digunakan, media, dan sikap guru saat mengajar; 3) Pada penilaian, terdapat beberapa perbedaan kriteria penilaian pada aspek sikap dan keterampilan baik untuk siswa laki-laki maupun perempuan.

3. Kelebihan dan Kekurangan Implementasi Pembelajaran Berdasarkan Gender di SMP Negeri 1 Kediri 
a. Kelebihan bagi siswa, antara lain: (a) menjadi lebih konsentrasi; (b) tidak malu untuk mengungkapkan pendapatnya; (c) menjadi lebih leluasa dalam bergaul di kelas; (d) adanya hubungan yang erat antar siswa karena memiliki kesamaan secara biologis; (e) meningkatkan motivasi belajar.

b. Kekurangan bagi siswa, antara lain: (a) motivasi belajar menjadi berkurang; (b) daya saing berkurang; (c) kelas laki-laki menjadi ribut; (d) perempuan cenderung bertingkah semena-mena seperti berteriak; (e) laki-laki tidak terlalu memperhatikan kebersihan kelas.

\section{Saran}

1. Siswa harus mampu mengikuti aturan yang telah dibuat oleh pihak sekolah terkait tujuan dari pemisahan kelas laki-laki dan perempuan.

2. Guru dapat meningkatkan inovasi dalam merancang rencana pembelajaran dan memilih metode pembelajaran yang sesuai dengan karakteristik siswa, sehingga metode yang digunakan tidak monoton.

3. Pihak sekolah dapat memfasilitasi siswa dengan menambah sarana dan prasarana yang dikhususkan untuk siswa laki-laki dan perempuan agar siswa-siswa tersebut tidak perlu berbaur ketika berada di luar kelas.

4. Pihak sekolah dapat konsisten menjalankan kebijakan ini agar menjadi sekolah model untuk pemisahan kelas laki-laki dan perempuan.

5. Kebijakan pemisahan kelas di SMP Negeri 1 Kediri ini dapat menjadi contoh bagi sekolah-sekolah umum yang lain dalam menerapkan pemisahan kelas antara siswa laki-laki dan perempuan.

\section{DAFTAR PUSTAKA}

Abuddin Nata. 2008. Manajemen Pendidikan Mengatasi Kelemahan Pendidikan Islam di Indonesia. Jakarta: Kencana Prenada Media Group.

Arikunto, S. 2013. Manajemen Penelitian. Jakarta: Rineka Cipta.

Arikunto, Suharsimi. 2002. Metodologi Penelitian. Jakarta: PT. Rineka Cipta.

Bungin, Burhan H. M. 2007. Penelitian Kualitatif. Jakarta: Kencana Prenama Media Group.

Hafizah Awalia. 2014. Pendidikan Gender Melalui Advokasi BP3AKB Provinsi NTB dalam Penyelesaian Tindakan Kekerasan dalam Rumah Tangga. Skripsi tidak diterbitkan. Mataram: Universitas Mataram.

Khuza'i, Muh. 2013. Problem Definisi Gender Kajian Atas Konsep Nature dan Nurture. Ponorogo.

Laelatussa'adah. Aplikasi Kesetaraan Gender Dalam Pendidikan Pada Sekolah-Sekolah Menengah Kecamatan Kresek Balaraja Banten. Jakarta: UIN Syarif Hidayatullah.

Miles. B Matthew dan Huberman, A Michael, 1992. Analisis Data Kualitatif. Jakarta: Universitas Indonesia Press. 
Vol. 6 No. 1, Oktober-Maret 2019, hh. 57-66

Nur, Gina Dewi Lestari. 2014. Pembelajaran Vocal Grup Dalam Kegatan Pembelajaran Diri di SMPN 1 Panumbangan Ciamis. Universitas Pendidikan Indonesia.

Purwanto dan Sulistyastuti. 1991. Analisis Kebijakan Dari Formulasi Ke Implementasi Kebijakan. Jakarta: Bumi Aksara.

Syaiful Sagala. 2009. Manajemen Strategik dalam Peningkatan Mutu Pendidikan. Bandung: Alfabeta Bandung. 